Governing the Family 
Also by Nigel Parton

The Politics of Child Abuse 


\section{Governing the Family}

Child Care, Child Protection and the State

Nigel Parton

Macmillan Education 
ISBN 978-0-333-54122-7 ISBN 978-1-349-21441-9 (eBook)

DOI 10.1007/978-1-349-21441-9

(C) Nigel Parton, 1991

Softcover reprint of the hardcover 1st edition 1991

All rights reserved. For information, write:

Scholarly and Reference Division,

St. Martin's Press, Inc., 175 Fifth Avenue,

New York, N.Y. 10010

First published in the United States of America in 1991

ISBN 978-0-312-06171-5

Library of Congress Cataloging-in-Publication Data

Parton, Nigel.

Governing the family: child care, child protection and the state

/Nigel Parton.

p. $\mathrm{cm}$.

Includes bibliographical references and index.

ISBN 978-0-312-06171-5

1. Child welfare-Great Britain. 2. Child abuse-Great Britain.

3. Child abuse-Great Britain-Prevention. 4. Family social work-Great Britain. I. Title.

HV751.A6P24 1991

$362.7^{\prime} 68-\mathrm{dc} 20$

$90-28660$

CIP 
For Rita and Bob 


\section{Contents}

List of Tables viii

Preface ix

1. Social Work, Social Regulation and the Family 1

2. Child Care, Prevention and Partnership 19

3. Child Abuse, Authority and Risk 52

4. Sexual Abuse, the Cleveland Affair and the Private Family

79

5. Co-ordination, Management and Social Assessment

6. The Children Act 1989: Reconstructing the Consensus

7. A Contemporary Political Economy of Child Protection

Notes

Bibliography

Index 


\section{List of Tables}

2.1 Number of children removed to a place of safety during the year April 1 to March 31 in England 1978-84

3.1 Number of children removed to a place of safety in England, years ending 31 March 1983-8

3.2 Child abuse and neglect high-risk checklist

3.3 Carlile Report hierarchy of state interventions in the family 


\section{Preface}

In some respects this study can be read as simply taking further the story and critical analysis first developed in The Politics of Child Abuse (1985b). In other ways, however, it is quite different. During the 1980s it seemed that a major shift emerged in the way the state attempted to prevent harm to children living in the family in Britain. Rather than emphasise the dual and sometimes competing concerns of stopping child abuse and improving child care, increasingly the focus was on a new activity - child protection. The 1989 Children Act and the various official guidance to professionals in the wake of the Cleveland inquiry gave expression to a new set of concepts, rules and practices which attempted to overcome the apparent crisis which seemed to characterise the child care system during the period. This could be seen as part of wider changes in state formation and social regulation in Britain in the 1980s illustrated by a series of measures affecting the social services and social policy more generally.

In order to make sense of these changes, a rather different conceptual and analytic toolkit was required therefore. Rather than being centrally concerned with analysing the emergence and impact of the problem of child abuse as previously, I am here concerned with, on the one hand, discussing a broader range of legal, regulatory and interventive strategies, while on the other, analysing in some detail the debates, recommendations for reform and the processes of policy change. The book therefore combines both a different conceptual framework and a closer attention to detail in order to explain the emergence of a new discourse focused around notions of child protection and family autonomy.

The book aims to help professionals - particularly social 
workers - working in the field, understand the nature of these changes and their impact on both their own role and responsibilities and the experiences of the men, women and children with whom they work. It also aims to provide a case study of the processes of change in social policy and make a contribution to current theoretical debates about the nature of social regulation in contemporary society.

I have accumulated numerous debts in the process of completing the project. Some of the ideas which inform the book first saw the light of day in previous smaller collaborative projects (Parton and Martin 1989; Parton and Parton 1989a, 1989b). Both Norma Martin and Christine Parton will recognise elements of that work here and must also take some responsibility for reawakening my interest and concerns in the area.

However, the opportunity to carry out the research which informs the book and the time to write it arose when I was lucky enough to be awarded a Hallsworth Fellowship during 1989-90. I would therefore like to thank both the Fellowship and the Department of Social Policy and Social Work at Manchester University for welcoming me and providing such a conducive environment for intensive study. Caroline Glendinning and Jean Ashton were crucial in this respect Caroline for both putting up with me and offering support and Jean for being so good-humoured and meticulous with the typing of what were supposed to be different drafts but in effect were very scrappy bits of paper. Barbara Bys assisted with the typing. Similarly, my long-suffering colleagues in the Social Work section at Huddersfield Polytechnic let me take up the Fellowship at a time of rapid change and severe resource constraint - one suspects, though, they coped better in my absence than if I had been present.

However, numerous others have had an impact on its content via their generous contributions of time and the sharing of their experiences and expertise. I would particularly like to thank Peter Smith and David Hinchliffe for their interest well beyond what could reasonably be hoped for. Discussions with Dennis Allen, Louis Blom-Cooper, Rupert Hughes, Barbara Kahan, Tina Lyons, Christine McKay, Tony Morrison, Neil Patrick, Mary Ryan, Nigel Speight, Jane Tunstill, and Avril 
Wilson were all invaluable. Robert Dingwall, Bob Franklin, Nick Frost, Christine Hallett, Jerry Johnstone, Michael King, Mark Philp, Nik Rose and Kevin Stenson all suggested articles and material which I have found most instructive. Finally, I would like to thank Bill Jordan, Jean Packman and Christine Parton for, particularly in the final case, living with the project throughout. Apart from offering generous support and encouragement, they have critically commented on every chapter and generally tried to keep me to the task in hand.

I am very conscious, however, that the particular interpretation I have put on things will vary from those that have been so generous and some may well feel I have missed the mark altogether. It is important to stress more than ever, therefore, that I am completely responsible for what follows.

Nigel Parton 